\title{
Predicted Versus Measured Tritium Oxide Concentrations at SRS (U)
}

by

\author{
A. A. Simpkins
}

Westinghouse Savannah River Company

Savannah River Site

Aiken, South Carolina 29808

DOE Contract No. DE-AC09-89SR18035

This paper was prepared in connection with work done under the above contract number with the U.S. Department of Energy. By acceptance of this paper, the publisher and/or recipient acknowledges the U.S. Government's right to retain a nonexclusive, royalty-free license in and to any copyright covering this paper, along with the right to reproduce and to authorize others to reproduce all or part of the copyrighted paper. 
Waste Management and

$\frac{\operatorname{lQ}_{\text {Srivi }}}{\text { Derivative Classifier }}$

\section{PREDICTED VERSUS MEASURED TRITIUM OXIDE CONCENTRATIONS AT SRS}

A. A. Simpkins $A$ A 2

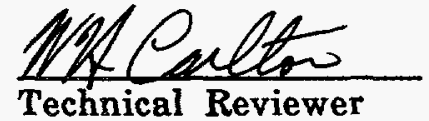

Technical Reviewer

December 1995

Savannah River Technology Center Westlnghouse Savannah River Company Alken, SC 29808

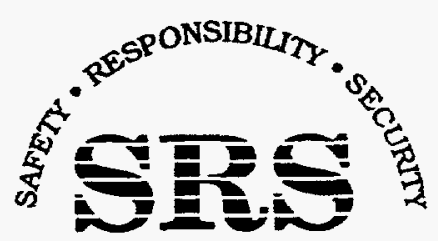

SAVANNAH RIVER SITE

PREPARED FOR THE U.S. DEPARTMENT OF ENERGY UNDER CONTRACT NO. DE-AC09-89SR18035 


\section{DISCLAIMER}

This report was prepared as an account of work sponsored by an agency of the United States Government. Neither the United States Government nor any agency thereof, nor any of their employees, makes any warranty, express or implied, or assumes any legal liability or responsibility for the accuracy, completeness, or usefulness of any information, apparatus, product, or process disclosed, or represents that its use would not infringe privately owned rights. Reference herein to any specific commercial product, process, or service by trade name, trademark, manufacturer, or otherwise does not necessarily constitute or imply its endorsement, recommendation, or favoring by the United States Government or any agency thereof. The views and opinions of authors expressed herein do not necessarily state or reflect those of the United States Government or any agency thereof.

This report has been reproduced directly from the best available copy.

Available to DOE and DOE contractors from the Office of Scientific and Technical Information, P.O. Box 62, Oak Ridge, TN 37831; prices available from (615) 576-8401.

Available to the public from the National Technical Information Service, U.S. Department of Commerce, 5285 Port Royal Road, Springfield, VA 22161. 


\title{
PREDICTED VERSUS MEASURED TRITIUM OXIDE CONCENTRATIONS AT SRS
}

\author{
A. A. Simpkins
}

Issued: December 1995 


\section{ABSIRACT}

Measured tritium oxide concentrations at various offsite locations are compared with concentrations predicted by three computer codes that are utilized at SRS to predict doses to the maximally exposed offsite individuals. Annual average concentrations predicted by the computer programs were compared with measured average concentrations taken from data contained in the last ten years of SRS Environmental Reports. The computer programs used for the comparison are AXAIRQ, CAP88, and MAXIGASP. 


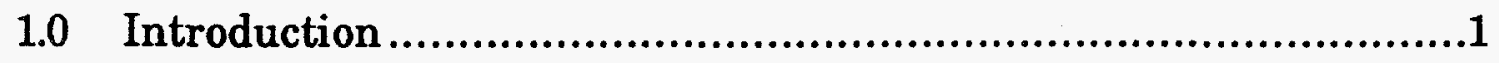

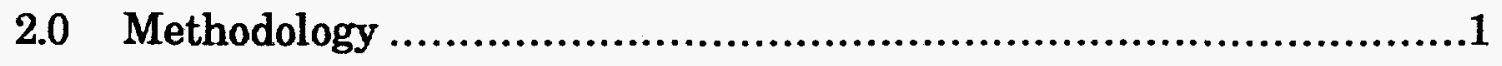

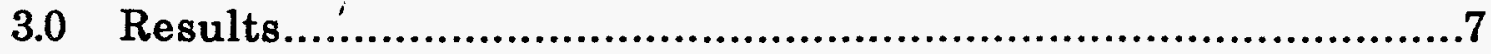

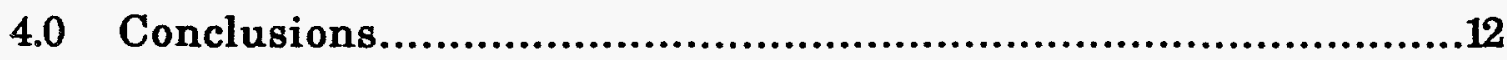

5.0 References.................................................................13

Appendix A. Tritium Oxide Concentrations ...............................15 


\section{LIST OF TABLES}

Table 1. Input parameters for Code Comparison..............................4

Table 2. Tritium Oxide Sampling Locations....................................7

Table 3. Tritium Oxide Released at SRS ...................................7

Table 4. Joint Frequency Distribution for $\mathrm{H}$ Area (all sectors) ...........9

\section{LIST OF FIGURES}

Figure 1. Wind Rose Data for $\mathrm{H}$ Area..........................................5

Figure 2. Air Monitoring Surveillance Stations at SRS ....................6

Figure 3. Predicted/Measured Tritium Oxide Concentrations at SRS Boundary Locations...................................................8

Figure 4. Predicted/Measured HTO Concentrations using

MAXIGASP with Terrain Effects and for Flat Earth .11 


\title{
PREDICTED VERSUS MEASURED TRITIUM OXIDE CONCENTRATIONS AT SRS
}

\author{
By A. A. Simpkins \\ Westinghouse Savannah River Company \\ Savannah River Site \\ Aiken, SC 29808
}

\subsection{INTRODUCTION}

Various computer models are used at the Savannah River Site (SRS) to predict the dose to a hypothetical maximally exposed offsite individual from atmospheric releases of radioactivity. Different computer models are used to predict doses for routine and accidental releases. AXAIRQ is used to predict doses following a hypothetical atmospheric accident. For routine releases, MAXIGASP is used to predict the dose to the maximally exposed offsite individual. For NESHAPS compliance, CAP88 is used to determine dose to the maximally exposed offsite individual. Each of these codes applies a Gaussian plume dispersion model with special features to account for a variety of weather conditions (i.e. fumigation or meander). All three of these codes predict average annual relative air concentrations.

Each year annual average tritium oxide concentrations at several boundary locations are reported in the SRS Environmental Report (Zeigler et al. 1986, 1987, Mikol et al. 1988, Davis et al. 1989, Cummins et al. 1990,1991, Arnett et al. 1992, 1993, 1994, 1995). The total amount of tritium oxide that is released from SRS facilities is continually monitored on-line at various potential release locations and is also reported in the Environmental Report.

Annual average tritium oxide concentrations are compared with the product of relative air concentrations predicted by AXAIRQ and MAXIGASP and the yearly amount of tritium oxide released. CAP88 displays the annual average tritium oxide concentration directly as part of the output. Differences between the programs and their conservatisms are discussed.

\subsection{METHODOLOGY}

Annual tritium oxide concentration results calculated using AXAIRQ, MAXIGASP, and CAP88 output are compared with data taken from SRS Environmental Reports for 1985-1994. 


\subsection{Computer Models Used}

Though used for different purposes, all three computer models have the ability to predict annual average relative air concentrations at various locations. Each of the programs are described briefly below.

\subsubsection{AXAIRQ}

AXAIRQ (Simpkins 1995a and 1995b) is primarily used to predict doses to the maximally exposed offsite individual following hypothetical accidental atmospheric releases of radioactive material. AXAIRQ is based on U.S. Nuclear Regulatory Commission (NRC) Regulatory Guide 1.145 (USNRC 1982) and releases can originate from either a vent or stack. Exposure pathways within AXAIRQ include: inhalation, ground shine, and plume shine. Primary applications include Safety Analysis Reports (SARs) and Hazard Assessments (HADs).

\subsubsection{MAXIGASP}

MAXIGASP (Bauer 1991 and Hamby 1992), which is used to predict offsite doses for routine releases of atmospheric radioactivity, is based on U.S. NRC Regulatory Guide 1.109 (USNRC 1977). MAXIGASP is a combination of two codes developed by the NRC: XOQDOQ and GASPAR. XOQDOQ (Sagendorf et al. 1982) predicts the downwind relative air concentrations based on a given set of input parameters. GASPAR (Eckerman et al. 1980) utilizes the output from XOQDOQ to predict doses for a variety of exposure pathways (inhalation, ingestion, plume shine, and ground shine.)

MAXIGASP is used primarily to predict doses to the maximally exposed offsite individual for the annual Environmental Report and various Environmental Impact Statements (EISs). MAXIGASP contains sitespecific land usage parameters (Hamby 1991).

\subsubsection{CAP88}

The Environmental Protection Agency (EPA) developed CAP88 (Beres 1990) to implement the mathematical models for assessing dose and risk due to radionuclide emissions to the air. CAP88 is used to demonstrate NESHAPS compliance (40CFR61). The following exposure pathways are considered: inhalation, ingestion, plume shine, and ground shine. None of the models within CAP888 have been modified for use at SRS, however, some of the 
default parameters have been changed to accurately reflect conditions that are typical at SRS (i.e. humidity).

\subsubsection{Annual Average Concentration Calculation}

Each of the computer programs predict annual average concentrations using the same basic equation. Annual average concentrations are determined by weighting each of the calculated concentrations in accordance with the probability of the occurrence using the following equation:

$$
\operatorname{annual}(\overline{\chi / Q})=\sum \mathrm{P}_{\mathrm{i}}\left(\frac{\chi}{\mathrm{Q}}\right)_{\mathrm{i}}
$$

where

$\mathrm{P}_{\mathrm{i}}=$ probability of a given set of meteorological conditions occurring $(\chi / Q)_{i}=$ sector arc average relative air concentration associated with the given set of meteorological conditions

Sector arc average relative air concentrations are determined using the following equation:

$$
\left(\frac{\chi}{Q}\right)(x, 0)=\frac{2.032 \mathrm{e}^{-\left(\frac{\left(\mathrm{b}_{\mathrm{o}}\right)^{2}}{2 \sigma_{\mathrm{z}}^{2}}\right)}}{\sigma_{\mathrm{z}} \mathrm{Ux}}
$$

where

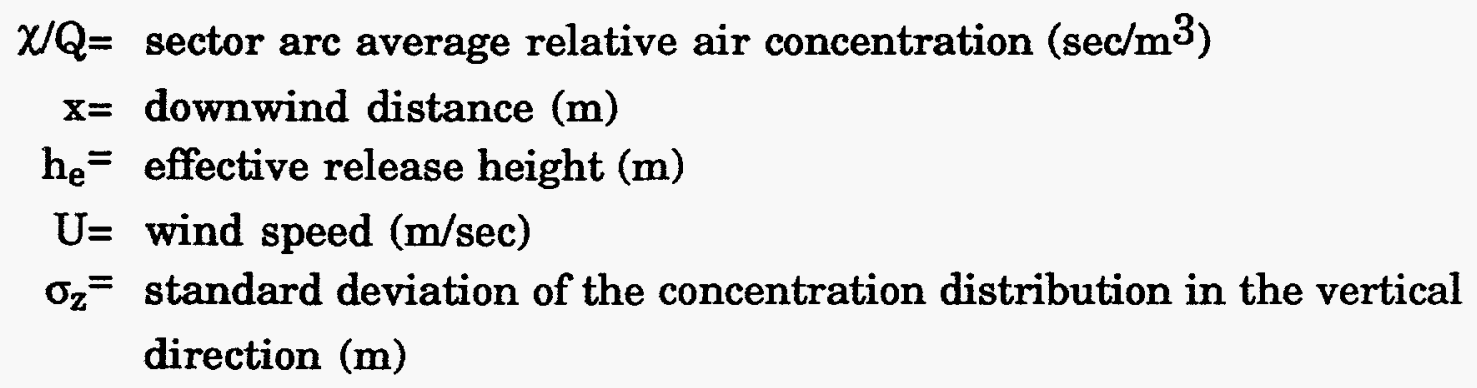

Each of the computer programs uses equations (1) and (2). However, parameters within the equations may differ within each program. These difference are discussed in the results section. 


\subsubsection{Computer Model Input}

Since each program has a different purpose, their associated inputs vary. Input data was kept as similar as possible. Table 1 shows the input parameters that were used. Parameters relating to dose are not shown since they do not affect the annual average concentration values.

Table 1. Input parameters for Code Comparison

\begin{tabular}{|l|l|}
\hline Parameter & Input \\
\hline Grid Coordinates & E 58000 and N 62000 \\
Meteorological data file accessed & H Area \\
Release Height & $61 \mathrm{~m}$ \\
Plume Rise & Options not activated \\
Diffusion Coefficients & Pasquill-Briggs (Different Formulas \\
& used for each) \\
Mixing Height & $1000 \mathrm{~m}$ \\
Source Term & $\mathrm{H}-3,1 \mathrm{Ci} / \mathrm{yr}$ \\
\hline
\end{tabular}

Meteorology from H Area for a five-year period (1987-1991) was used as input for each of the computer codes. At SRS meteorological data is collected at eight onsite towers. The most complete set of data is for $\mathrm{H}$ Area which is near the center of the site. Meteorological data is based on a joint frequency distribution of hourly averages for the entire five year period. The hourly averages are based on readings of the fluctuation of wind direction collected every 15 seconds. The results are grouped into seven stability categories (A-G) and six wind speed classes. Figure 1 shows the wind rose for SRS for 1987-1991. As seen in the figure, the most frequent wind direction is toward the SW.

\subsection{Existing Tritium Oxide Data}

Tritium oxide is sampled biweekly using silica gel samples which collect moisture from air pumped through a column. Water is removed from the silica gel by distilling over low heat. The distillate is mixed with a liquid scintillation cocktail, and a liquid scintillation counter is then used to determine the tritium oxide concentration in the atmospheric moisture. Daily atmospheric humidity values are used to convert to tritium oxide concentration in air (Cummins, et al. 1991). 

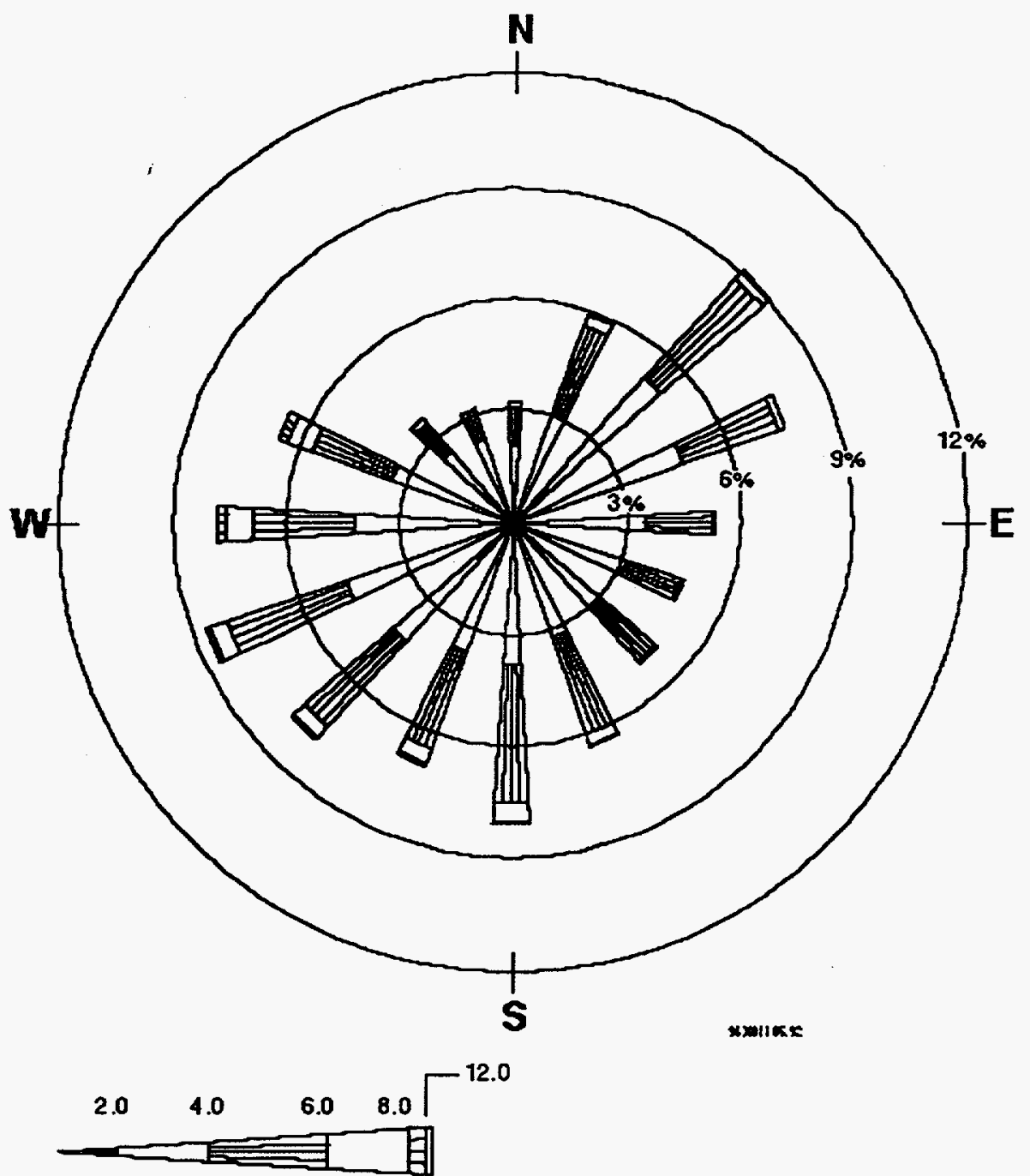

Wind Speed Cless Boundaries (Mitersiseond)

Figure 1. Wind Rose Data for H Area

(Indicates frequency $(\%)$ of wind from the specified direction)

The tritium oxide concentrations in air at 13 perimeter locations are compared with predicted concentrations from the dose assessment computer codes. The location of each of the collection points is shown in Figure 2. Table 2 shows a list of the perimeter locations and the distance from the center of the site to each location and the corresponding sector. Measured concentrations at each location are shown in Appendix A for 
1985-1994. In the Environmental Reports, the data for 1991 and 1994 displayed concentrations as tritium oxide in atmospheric moisture. A site specific humidity value of $11.4 \mathrm{~g} / \mathrm{m}^{3}$ (Hamby 1993) was used to convert the tritium oxide concentration in moisture to concentration in air. Appendix A also shows the computer predicted concentrations.

Tritium oxide releases over the past ten years are shown in Table 3 . Releases primarily originated from the Reactor and Separations Areas and the percentage released from each is also shown in Table 3. Referring to Figure 1, Reactor Areas are noted as C, K, L, P, and R and Separations Areas are noted as $\mathrm{F}$ and $\mathrm{H}$. Releases from other areas are negligible $(<1 \%)$.

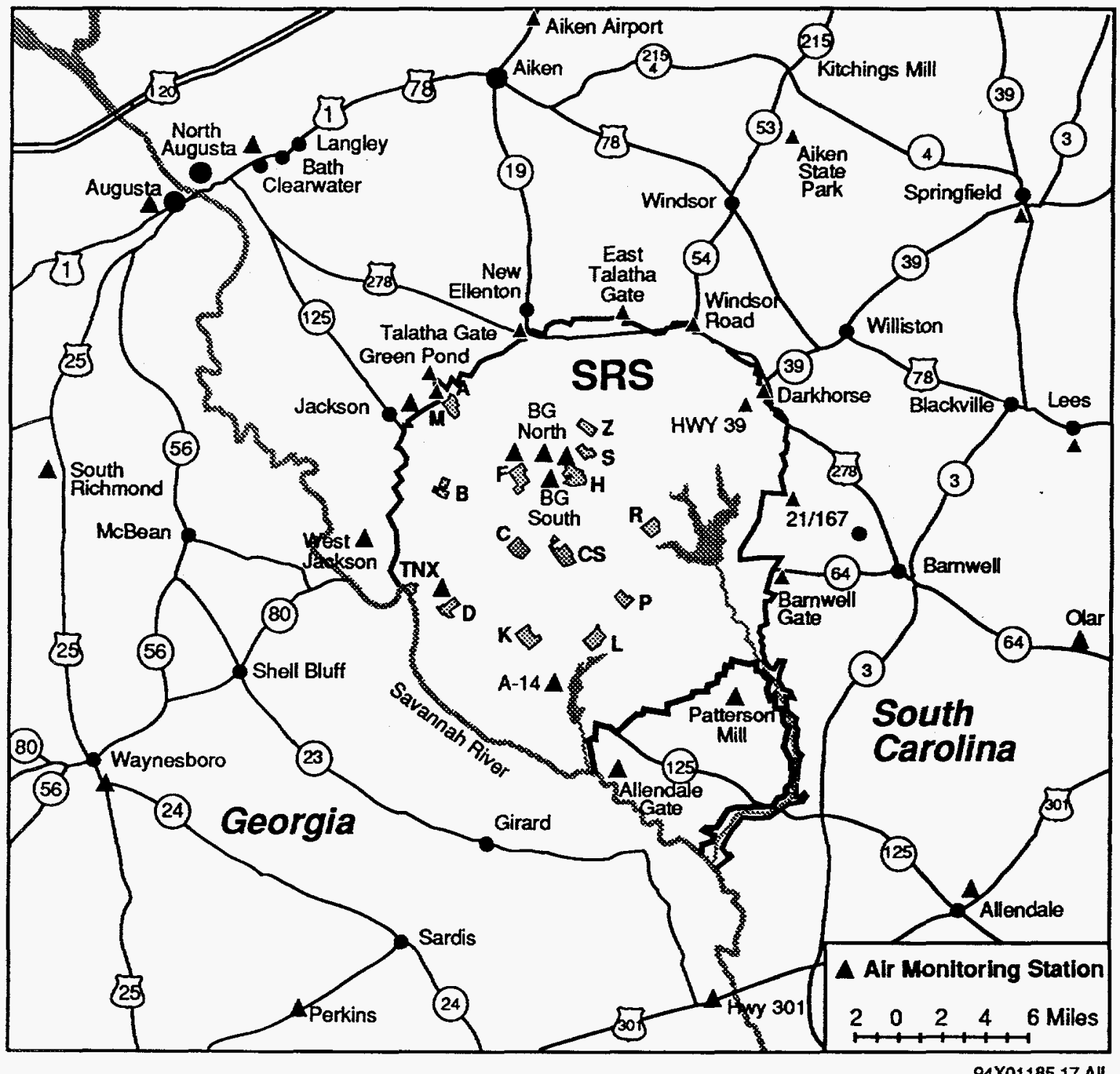

Figure 2. Air Monitoring Surveillance Stations at SRS 
Table 2. Tritium Oxide Sampling Locations

\begin{tabular}{|c|l|c|}
\hline Sector & \multicolumn{1}{|c|}{ Location } & $\begin{array}{c}\text { Distance from } \\
\text { Center of Site (m) }\end{array}$ \\
\hline N & E. Talatha Gate & 15977 \\
NNE & Windsor Road & 17825 \\
NE & Darkhorse & 17463 \\
ENE & Highway 21/167 & 16603 \\
E & Barnwell Gate & 14926 \\
SE & Patterson Mill & 15518 \\
SSE & Allendale Gate & 15322 \\
SSW & A-14 & 8658 \\
WSW & D Area & 10663 \\
W & West Jackson & 13061 \\
WNW & Jackson & 15258 \\
NW & Green Pond & 14484 \\
NNW & Talatha Gate & 14362 \\
\hline
\end{tabular}

Table 3. Tritium Oxide Released at SRS

\begin{tabular}{|c|c|c|c|}
\hline Year & $\begin{array}{c}\text { Amount } \\
\text { Released (Ci) }\end{array}$ & $\begin{array}{c}\text { Released from } \\
\text { Reactors }\end{array}$ & $\begin{array}{c}\text { Released from } \\
\text { Separations }\end{array}$ \\
\hline 1985 & $4.87 \mathrm{E}+05$ & $54 \%$ & $46 \%$ \\
1986 & $2.85 \mathrm{E}+05$ & $46 \%$ & $54 \%$ \\
1987 & $2.70 \mathrm{E}+05$ & $37 \%$ & $63 \%$ \\
1988 & $2.88 \mathrm{E}+05$ & $38 \%$ & $62 \%$ \\
1989 & $2.18 \mathrm{E}+05$ & $60 \%$ & $40 \%$ \\
1990 & $1.75 \mathrm{E}+05$ & $45 \%$ & $55 \%$ \\
1991 & $1.37 \mathrm{E}+05$ & $55 \%$ & $45 \%$ \\
1992 & $1.00 \mathrm{E}+05$ & $47 \%$ & $53 \%$ \\
1993 & $1.33 \mathrm{E}+05$ & $29 \%$ & $71 \%$ \\
1994 & $1.07 \mathrm{E}+05$ & $22 \%$ & $78 \%$ \\
\hline
\end{tabular}

\subsection{RESULTS}

Concentrations at the 13 site boundary perimeter locations are compared to output from AXAIRQ, MAXIGASP, and CAP88. The predicted annual average air concentration at the specific boundary location (for a $1 \mathrm{Ci}$ release) is multiplied by the total amount of tritium oxide released for the year to determine the annual average tritium oxide concentration. This result is divided by the measured average tritium oxide concentration to determine the "predicted to measured ratio." These ratios are averaged using different combinations to study various effects. 


\subsection{0-Year Concentration Comparison}

For each year, the ratios of predicted to measured tritium oxide concentrations from the 13 perimeter locations are averaged. The results using each of the three codes are shown in Figure 3. For each year AXAIRQ shows the greatest difference of predicted to measured tritium oxide concentrations. The 10-yr average of the ratio of differences for AXAIRQ, MAXIGASP, and CAP88 is $1.89 \pm 0.56,1.70 \pm 0.48$, and $1.40 \pm 0.39$, respectively. AXAIRQ is the most conservative since the primary use of the code is for accident analysis.

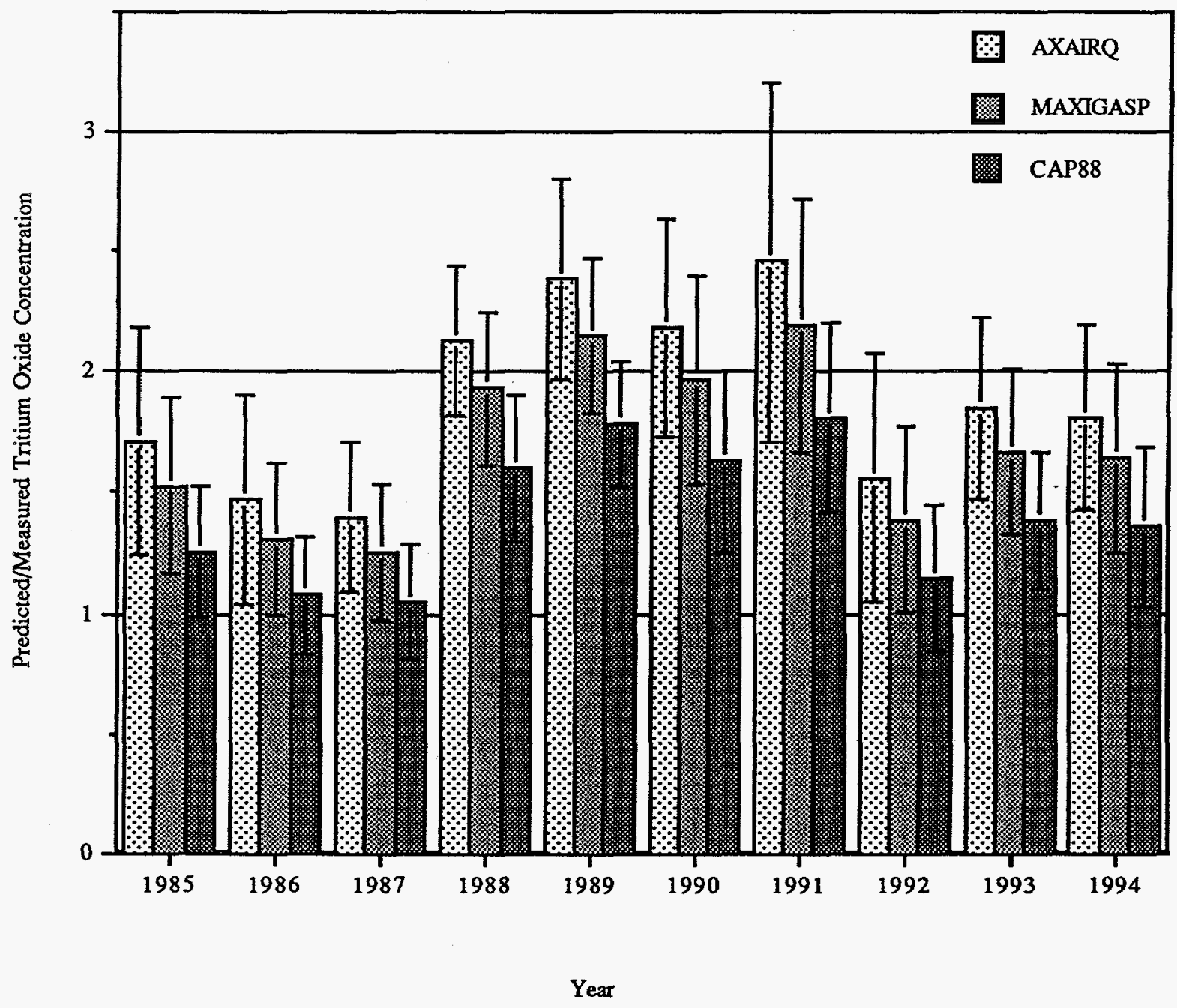

Figure 3. Predicted/Measured Tritium Oxide Concentrations at SRS Boundary Locations 


\subsection{Explanation of Variation of Predicted Values}

Several differences in code structure contribute to variations in predicted tritium oxide concentrations. The primary difference is the treatment of wind speed averages.

\subsubsection{Wind Speed Averages}

While each code accesses the same meteorological frequency distribution, each of the three codes uses different methodologies to calculate wind speed averages for the relative air concentration calculations. Table 4 shows the frequency distribution summed for all sectors for each of the 42 stability category and wind speed class combinations. The predominant wind speed classes are two and three. No stability class occurs considerably more than any of the others although stability classes $F$ and $G$ occur the least amount of time.

Table 4. Joint Frequency Distribution for $\mathrm{H}$ Area (all sectors)

\begin{tabular}{|c|c|c|c|c|c|c|c||c|}
\hline \multirow{2}{*}{ WS } & \multicolumn{7}{|c|}{ STABILTYCLASS } & \multirow{2}{*}{ TOTAL } \\
\cline { 2 - 9 } & $\mathrm{A}$ & $\mathrm{B}$ & $\mathrm{C}$ & $\mathrm{D}$ & $\mathrm{E}$ & $\mathrm{F}$ & $\mathrm{G}$ & TTA \\
\hline 1 & $6 \%$ & $1 \%$ & $1 \%$ & $1 \%$ & $0 \%$ & $0 \%$ & $0 \%$ & $9 \%$ \\
2 & $14 \%$ & $6 \%$ & $9 \%$ & $10 \%$ & $7 \%$ & $1 \%$ & $0 \%$ & $47 \%$ \\
3 & $3 \%$ & $4 \%$ & $7 \%$ & $10 \%$ & $10 \%$ & $2 \%$ & $0 \%$ & $37 \%$ \\
4 & $0 \%$ & $1 \%$ & $2 \%$ & $1 \%$ & $0 \%$ & $0 \%$ & $0 \%$ & $5 \%$ \\
5 & $0 \%$ & $0 \%$ & $1 \%$ & $0 \%$ & $0 \%$ & $0 \%$ & $0 \%$ & $1 \%$ \\
6 & $0 \%$ & $0 \%$ & $0 \%$ & $0 \%$ & $0 \%$ & $0 \%$ & $0 \%$ & $0 \%$ \\
\hline \hline TOTAL & $\mathbf{2 4} \%$ & $12 \%$ & $20 \%$ & $23 \%$ & $17 \%$ & $4 \%$ & $0 \%$ & $100 \%$ \\
\hline
\end{tabular}

The meteorological data files accessed by AXAIRQ contain wind speed averages for each of the 16 sectors and 42 stability class and wind speed combinations. These 672 values are the actual harmonic average wind speeds over the five year period for the sector, stability category, and wind speed class of interest. The wind speed ranges for each of the six categories are: $0-2,2-4,4-6,6-8,8-12$, and $>12 \mathrm{~m} / \mathrm{s}$.

MAXIGASP contains a set of constant wind speed values that correspond to each of the six wind speed classes. The values used by MAXIGASP, which correspond to wind speed classes 1-6, are: $1,3,5,7,9,10$, and $13.05 \mathrm{~m} / \mathrm{s}$. Regardless of which sector or stability class is accessed, the same wind speed is used for a given wind speed class. 
CAP88 uses a harmonic average wind speed value for each stability class and sector. Therefore, 112 (16 sectors and 7 stability categories) different values are used for the calculations. These values generally show only slight variations from stability class $A-G$ with typical values ranging from $2.5-4.0 \mathrm{~m} / \mathrm{s}$.

As seen in equation 2, the wind speed is inversely proportional to the sector arc average relative air concentration. Since CAP88 wind speed values are determined by weighting the various wind speed values within a given stability class, the values are higher than the values used by AXAIRQ and MAXIGASP, therefore, resulting in lower concentrations.

\subsubsection{Mixing Height}

Mixing height is set to a constant value of $1000 \mathrm{~m}$ in MAXIGASP and CAP88. Mixing height is a user input value in AXAIRQ and the value was set at $1000 \mathrm{~m}$ for this comparison. The average observed mixing height for SRS in 1978 was $1260 \mathrm{~m}$ (Garrett 1981). Monthly observed mixing heights were under 1000 but greater than 900 for only 2 months of the year. The mixing height value of $1000 \mathrm{~m}$ is conservative with respect to yearly average observed values. AXAIRQ limits the value of the vertical diffusion coefficient $\left(\sigma_{\mathrm{z}}\right)$ to $80 \%$ of the value of the mixing height. Both CAP88 and MAXIGASP limit the vertical diffusion coefficient to a value equal to the mixing height. Since relative air concentration is inversely proportional to vertical diffusion coefficient, AXAIRQ estimates a higher value for relative air concentration. This is the primary difference between AXAIRQ and MAXIGASP.

\subsubsection{Terrain}

Both AXAIRQ and MAXIGASP adjust the height of the release according to terrain height at the location of the receptor. CAP88 does not account for terrain. Terrain data was provided by Oak Ridge National Lab (ORNL) for a grid surrounding the site. AXAIRQ and MAXIGASP convert this grid to a polar coordinate system centered on the release location. The terrain height at the location of the receptor is assumed to be the maximum terrain height difference between the receptor and the release location. The height of the plume is reduced by the maximum terrain height between the plume and the receptor.

MAXIGASP has a feature that allows the user to utilize terrain effects or assume flat earth. The code was executed using both methods. The predicted versus measured tritium oxide concentrations are shown in Figure 4 with and without terrain effects. The 10-year average with terrain 
considered is $1.70 \pm 0.48$ and the 10 -year average for flat earth is $1.57 \pm 0.66$. These differences are slight in comparison to differences due to wind speed averaging.

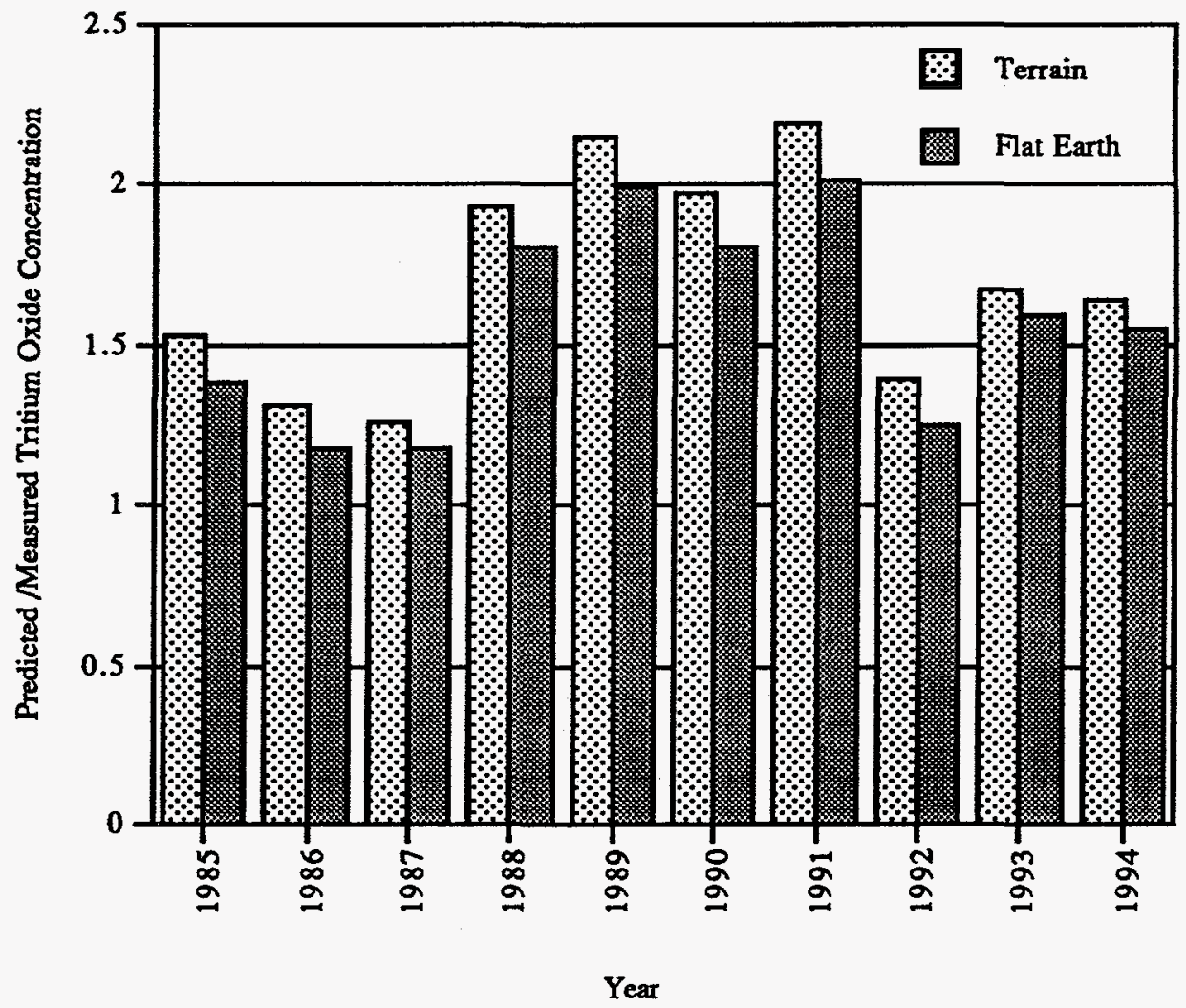

Figure 4. Predicted/Measured Tritium Oxide Concentrations using MAXIGASP with Terrain Effects and for Flat Earth

\subsubsection{Release Types}

Over the years releases occurred from various locations and release heights. While the bulk of the releases originate from the center of the site, a few of the releases were actually closer to the boundary. Some of the releases may not have occurred at a stack height of $61 \mathrm{~m}$, but at ground level. Additional analysis is needed to determine the effect of these parameters. 


\subsubsection{Differences in Dose Predictions}

Each of the three computer codes predict dose differently and use different exposure pathways. The differences in concentration are therefore not indicative of the difference in dose for each of the programs. Both CAP88 and MAXIGASP predict doses to the maximally exposed offsite individual based on annual average concentrations as used in this study. AXAIRQ calculates dose for meteorological conditions not exceeded $99.5 \%$ of the time dependent on sector or $50 \%$ or $95 \%$ independent of sector.

\subsection{CONCLUSIONS}

Various dose assessment computer programs used at SRS over predict the offsite tritium oxide concentrations by a factor of $1.4-2.0$. Since annual average concentrations are typically predicted within a factor of two to four using Gaussian plume models (Miller et al. 1987), these results show exceptional agreement. Each of the computer models follows appropriate regulatory guidance and any attempt to change currently acceptable methodology would require extensive site-specific studies and significant technical justification. 


\subsection{REFEREINCES}

Arnett, M.W., Karapatakis, L. K., Mamatey, A.R., and Todd, J.L. 1992, Savannah River Site Environmental Report for 1991(U). WSRC-TR92-186, Westinghouse Savannah River Company, Aiken, SC.

Arnett, M. W., Karapatakis, L. K., and Mamatey, A.R., 1993, Savannah River Site Environmental Report for 1992(U), WSRC-TR-93-075, Westinghouse Savannah River Company, Aiken, SC.

Arnett, M. W., Karapatakis, L. K., and Mamatey, A.R., 1994, Savannah River Site Environmental Report for 1993(U), WSRC-TR-94-075, Westinghouse Savannah River Company, Aiken, SC.

Arnett, M. W., Mamatey, A.R., and Spitzer, D. 1995, Savannah River Site Environmental Report for 1994(U), WSRC-TR-95-075, Westinghouse Savannah River Company, Aiken, SC.

Bauer, L.R. 1991 Modeling Chronic Atmospheric Releases at the SRS: Evaluation and Verification of XOQDOQ, WSRC-RP-91-320, Westinghouse Savannah River Company, Aiken, SC.

Beres, D.A. 1990 The Clean Air Act Assessment Package-1988 (CAP88) A Dose and Risk Assessment Methodology for Radionuclide Emissions to Air, U.S. Environmental Protection Agency, Washington, D.C.

Cummins, C.L., Martin, D.K., and Todd, J.L. 1990, Savannah River Site Environmental Report for 1989(U), Volume I, WSRC-IM-90-60, Westinghouse Savannah River Company, Aiken, SC.

Cummins, C.L., Martin, D.K., and Todd, J.L. 1991, Savannah River Site Environmental Report for 1990(U), Volume 1, WSRC-IM-91-28, Westinghouse Savannah River Company, Aiken, SC.

Davis, H.A., Martin, D.K., and Todd, J.L. 1989, Savannah River Site Environmental Report for 1988(U), Volume I, WSRC-RP-89-59-1, Westinghouse Savannah River Company, Aiken, SC.

Eckerman, K.F., Congel, F.J., Roecklein, A.K., and Pasciak, W.J. 1980 User's Guide to GASPAR Code, NUREG/-0597, U.S. Nuclear Regulatory Commission, Washington, D.C.

Garrett, A.J. 1981, "Comparison of Observed Mixed-Layer Depths to Model Estimates Using Observed Temperatures and Winds, and MOS Forecasts", Journal of Applied Meteorology, November.

Hamby, D.M. 1991 Land and Water User Characteristics in the Vicinity of the Savannah River Site(U), WSRC-RP-91-17, Westinghouse Savannah River Company, Aiken, SC. 
Hamby, D.M. 1992 Verification of the GASPAR Dose Assessment Module used in MAXIGASP and POPGASP, WSRC-RP-92-418, Westinghouse Savannah River Company, Aiken, SC.

Hamby, D.M. 1993 A Probabilistic Estimation of Atmospheric Tritium Dose. Health Physics, 65:33-40.

Mikol, S.C., Burckhalter, L.T., Todd, J.L., and Martin, D.K. 1988, Savannah River Plant Environmental Report for 1987(U), Volume I, DPSPU-88-30-1, E. I. du Pont de Nemours and Co., Savannah River Plant, Aiken, SC.

Miller, C. W., Hively, L.M. 1987, A Review of Validation Studies for the Gaussian Plume Atmospheric Dispersion Model. Nuclear Safety. 28:522-531.

Sagendorf, J.F., Goll, J.T., and Sandusky, W.F. 1982 XOQDOQ: Computer Program for the Meteorological Evaluation of Routine Effluent Releases at Nuclear Power Stations, NUREG/CR-2919, U.S. Nuclear Regulatory Commission, Washington, D.C.

Simpkins, A.A. 1995a Verification of AXAIRQ, WSRC-RP-95-708, Westinghouse Savannah River Company, Aiken, SC.

Simpkins, A.A. 1995b User's Manual for AXAIRQ, WSRC-RP-95-709, Westinghouse Savannah River Company, Aiken, SC.

USNRC 1977 Calculation of Annual Doses to Man from Routine Releases of Reactor Effluents for the Purpose of Evaluating Compliance with 10 CFR 20, Appendix I, U.S. NRC Regulatory Guide 1.109 Rev. 1, U.S. Nuclear Regulatory Commission, Washington, D.C.

USNRC 1982 Atmospheric Dispersion Models for Potential Accident Consequence Assessments at Nuclear Power Plants, U.S. NRC Regulatory Guide 1.145, Rev. 1, U.S. Nuclear Regulatory Commission, Washington, D.C., November.

Zeigler, C.C., Lawrimore, I.B., Heath, E.M., and Till, J.E. 1986, Savannah River Plant Environmental Report for 1985(U), Volume I, DPSPU-8630-1, E. I. du Pont de Nemours and Co., Savannah River Plant, Aiken, SC.

Zeigler, C.C., Heath, E.M., Taus, L.B., and Todd, J.L. 1987, Savannah River Plant Environmental Report for 1986(U), Volume I, DPSPU-8730-1, E. I. du Pont de Nemours and Co., Savannah River Plant, Aiken, SC. 


\section{Appendix A. Tritium Oxide Concentrations}

Table A1. Air Concentrations at Various Offsite Locations

\begin{tabular}{|c|l|c|c|c|c|c|}
\hline \multirow{2}{*}{ Sector } & Location & \multicolumn{5}{|c|}{ Air Concentration (pCi/m ${ }^{3}$ ) } \\
\cline { 2 - 6 } N & E. Talatha Gate & 1985 & 1986 & 1987 & 1988 & 1989 \\
NNE & Windsor & 120 & 64 & 71 & 51 & 34 \\
NE & Darkhorse & 110 & 73 & 66 & 58 & 33 \\
ENE & Highway 21/167 & 99 & 73 & 160 & 50 & 34 \\
E & Barnwell Gate & 97 & 75 & 57 & 42 & 36 \\
SE & Patterson Mill & 75 & 52 & 41 & 35 & 33 \\
SSE & Allendale Gate & 50 & 48 & 33 & 24 & 20 \\
SSW & A-14 & 140 & 140 & 88 & 65 & 20 \\
WSW & D Area & 310 & 140 & 140 & 90 & 74 \\
W & W. Jackson & 130 & 73 & 71 & 50 & 33 \\
WNW & Jackson & 97 & 64 & 64 & 47 & 29 \\
NW & Green Pond & 120 & 72 & 75 & 64 & 31 \\
NNW & Talatha Gate & 110 & 76 & 110 & 86 & 50 \\
\hline
\end{tabular}

Table A1. continued. Air Concentrations at Various Offsite Locations

\begin{tabular}{|c|l|c|c|c|c|c|}
\hline & & \multicolumn{5}{|c|}{ Air Concentration $\left(\mathrm{pCi} / \mathrm{m}^{3}\right)$} \\
\cline { 2 - 6 } Sector & Location & 1990 & 1991 & 1992 & 1993 & 1994 \\
\hline N & E. Talatha Gate & 31 & 26 & 24 & 29 & 27 \\
NNE & Windsor & 27 & $2^{*}$ & 31 & 26 & 28 \\
NE & Darkhorse & 26 & $2^{*}$ & 26 & 30 & 25 \\
ENE & Highway 21/167 & 27 & 19 & 21 & 27 & 18 \\
E & Barnwell Gate & 27 & 19 & 19 & 26 & 17 \\
SE & Patterson Mill & 22 & 18 & 20 & 14 & 12 \\
SSE & Allendale Gate & 19 & 16 & 17 & 9 & 14 \\
SSW & A-14 & 34 & 29 & 36 & 38 & 20 \\
WSW & D Area & 56 & 39 & 53 & 60 & 43 \\
W & W. Jackson & 33 & 22 & 26 & 27 & 19 \\
WNW & Jackson & 30 & 18 & 24 & 36 & 16 \\
NW & Green Pond & 40 & 18 & 24 & 32 & 22 \\
NNW & Talatha Gate & 44 & 22 & 23 & 36 & 31 \\
\hline
\end{tabular}

* Data point ignored because not in range of minimum to maximum as displayed in Environmental Report. 
Concentrations listed in Table A2 are multiplied by the total amount of tritium oxide released for a given year (see Table 3 ). This predicted tritium oxide concentration for a given year and location is compared with the actual concentrations in Table A1.

Table A2. Concentrations per Unit Release Predicted by the Computer Programs

\begin{tabular}{|c|l|c|c|c|c|}
\hline Sector & Location & $\begin{array}{c}\text { Distance } \\
(\mathrm{m})\end{array}$ & $\begin{array}{c}\text { AXAIRQ } \\
\left(\mathrm{pCi} / \mathrm{m}^{3}\right)\end{array}$ & $\begin{array}{c}\text { MAXIGASP } \\
\left(\mathrm{pCi} / \mathrm{m}^{3}\right)\end{array}$ & $\begin{array}{c}\text { CAP88 } \\
\left(\mathrm{pCi} / \mathrm{m}^{3}\right)\end{array}$ \\
\hline $\mathrm{N}$ & E. Talatha Gate & 15977 & $4.89 \mathrm{E}-04$ & $4.48 \mathrm{E}-04$ & $3.80 \mathrm{E}-04$ \\
$\mathrm{NNE}$ & Windsor Road & 17825 & $3.89 \mathrm{E}-04$ & $3.37 \mathrm{E}-04$ & $2.70 \mathrm{E}-04$ \\
$\mathrm{NE}$ & Darkhorse & 17463 & $3.81 \mathrm{E}-04$ & $3.56 \mathrm{E}-04$ & $3.00 \mathrm{E}-04$ \\
$\mathrm{ENE}$ & Highway 21/167 & 16603 & $3.83 \mathrm{E}-04$ & $3.51 \mathrm{E}-04$ & $3.00 \mathrm{E}-04$ \\
$\mathrm{E}$ & Barnwell Gate & 14926 & $3.74 \mathrm{E}-04$ & $3.28 \mathrm{E}-04$ & $2.80 \mathrm{E}-04$ \\
$\mathrm{SE}$ & Pattersons Mill & 15518 & $2.00 \mathrm{E}-04$ & $1.88 \mathrm{E}-04$ & $1.60 \mathrm{E}-04$ \\
$\mathrm{SSE}$ & Allendale Gate & 15322 & $1.68 \mathrm{E}-04$ & $1.58 \mathrm{E}-04$ & $1.30 \mathrm{E}-04$ \\
SSW & A-14 & 8658 & $5.11 \mathrm{E}-04$ & $5.24 \mathrm{E}-04$ & $4.30 \mathrm{E}-04$ \\
WSW & D Area & 10663 & $5.96 \mathrm{E}-04$ & $5.56 \mathrm{E}-04$ & $4.80 \mathrm{E}-04$ \\
W & West Jackson & 13061 & $3.37 \mathrm{E}-04$ & $2.99 \mathrm{E}-04$ & $2.70 \mathrm{E}-04$ \\
WNW & Jackson & 15258 & $2.88 \mathrm{E}-04$ & $2.62 \mathrm{E}-04$ & $2.10 \mathrm{E}-04$ \\
NW & Green Pond & 14484 & $4.35 \mathrm{E}-04$ & $3.65 \mathrm{E}-04$ & $2.80 \mathrm{E}-04$ \\
NNW & Talatha Gate & 14362 & $6.48 \mathrm{E}-04$ & $4.95 \mathrm{E}-04$ & $3.70 \mathrm{E}-04$ \\
\hline
\end{tabular}


REFERENCES for Appendix A.

References are listed in ascending order by year.

Zeigler, C.C., Lawrimore, I.B., and Heath, E.M. 1986, Savannah River Plant Environmental Report for 1985(U), Volume II, DPSPU-86-30-1, E. I. duPont de Nemours and Co., Savannah River Plant, Aiken, SC.

Zeigler, C.C., Heath, E.M., Taus, L.B., Todd, J.L., and Till, J.E. 1987, Savannah River Plant Environmental Report for 1986(U), Volume II, DPSPU-87-30-1, E. I. du Pont de Nemours and Co., Savannah River Plant, Aiken, SC.

Mikol, S.C., Burckhalter, L.T., Todd, J.L., and Martin, D.K. 1988, Savannah River Plant Environmental Report for 1987(U), Volume II, DPSPU-88-30-1, E. I. du Pont de Nemours and Co., Savannah River Plant, Aiken, SC.

Advise, H.A., Martin, D.K., and Todd, J.L. 1989, Savannah River Site Environmental Report for 1988(U), Volume II, WSRC-RP-89-59-1, Westinghouse Savannah River Company, Aiken, SC.

Cummins, C.L., Martin, D.K, and Todd, J.L. 1990, Savannah River Site Environmental Report for 1989(U), Volume II, WSRC-IM-90-60, Westinghouse Savannah River Company, Aiken, SC.

Cummins, C.L., Martin, D.K., and Todd, J.L. 1991, Savannah River Site Environmental Report for 1990(U), Volume 1, WSRC-IM-91-28, Westinghouse Savannah River Company, Aiken, SC.

Arnett, M.W., Karapatakis, L. K., Mamatey, A.R., and Todd, J.L. 1992, Savannah River Site Environmental Report for 1991(U). WSRC-TR92-186, Westinghouse Savannah River Company, Aiken, SC.

Arnett, M. W. 1993, Savannah River Site Environmental Data for 1992(U), WSRC-TR-93-077, Westinghouse Savannah River Company, Aiken, SC.

Arnett, M.W., 1994, Savannah River Site Environmental Data for 1993(U), WSRC-TR-94-077, Westinghouse Savannah River Company, Aiken, SC.

Arnett, M.W., 1995, Savannah River Site Environmental Data for 1994(U), WSRC-TR-95-077, Westinghouse Savannah River Company, Aiken, SC. 


\section{Distribution List(10)}

A.L. Boni, 773-A

W.H. Carlton, 773-A

J. D. Heffner, 735-16A

G.T. Jannik, 773-A

R. Lorenz, 735-16A

K.R. O'Kula, 992-1W

L.M. Papouchado, 773-A

A.A. Simpkins, 773-A

EDG Files, (3), 773-A 